\title{
Influence of Climate Changes and Low-Cost Garlic from China for Traditional Producers in the Czech Republic
}

\author{
Lukáš STEHLÍK, Martina HEDVIČÁKOVÁ \\ University of Hradec Králové, Hradec Králové, Czech Republic \\ lukas.stehlik@uhk.cz, martina.hedvicakova@uhk.cz
}

\begin{abstract}
The aim of this article is to analyze the position of the Czech garlic in the domestic market to justify the reasons for the initial sharp decline in demand around the year 2000, to determine the reasons for the return of interest for this product and to evaluate offers flexibility Czech manufacturers. Because of the outlined development it was found that the initially sharp decline in demand for Czech garlic declined his offer to almost a complete stop Czech production of this crop. This situation lasted until around 2008 when it began to slow due to certain awakening consumers about the unique qualities domestic product, demand for Czech garlic grow again. However, the offer did not respond adequately to this situation. In the meantime, interest in Czech garlic has risen several times and the offer is stagnating to date. The price of Czech garlic, which has been increasing in recent years due to a large overhang of demand over the supply. For the sake of interest, the situation on the domestic market is confronted with production in the European Union, in China, which is the world's garb of great powers with worldwide production.
\end{abstract}

Keywords: Czech garlic, Consumption, Demand, Production, Price.

\section{Introduction}

The fruit and vegetable trade are very volatile and depends on a number of different, often very badly influenced factors. Significant changes in demand, supply, general perception of the commodity by consumers and its position on the domestic market, which occurred in the case of Czech garlic, in addition for a very short period, however, do not even exist in this changing business environment.

Garlic originated from Central Asia about 3000 years and later spread to the Mediterranean regions [8]. Growing demand for vegetables is considered to have a favourable economic effect on smallholders. [2] Onion and garlic are two important vegetables in the world, which are processed in various forms such as powder, puree, and minced paste [9]. Garlic growing has always been a great tradition in the Czech Republic. This product, thanks to its high quality, maintained its permanent position on the domestic market, it was all available and considered to be a completely natural crop of domestic agriculture. The typical growing area was Uherskohradišt'sko, to this day are mainly known villages like Bánov, Dolní Němčí and Suchá Loz. An insignificant amount of garlic also flowed from the production of Czech gardeners 
and thanks to which the Czech Republic was completely self-sufficient in the production of garlic. So, there was little need to import garlic from abroad, and that is why this crop did not really threaten foreign competition. This fact ensured the Czech garlic the exclusive position on the domestic market. The total annual production of Czech garlic until 2000 was approximately 7000 tons, the roughly equivalent to annual domestic consumption. The retail price for consumers ranged between CZK 50, - to 70, - per kilogram. For comparison, today, only 1769 tons of these crops are grown in the Czech Republic and its selling price is up to CZK 200, - per kilogram. Agriculture experts agree that no other commodity in the fruit and vegetable sales has gone through so much economic change as Czech garlic in recent years. [1-4], [7]

\section{$2 \quad$ Methodology and objectives}

The article is based on primary and secondary sources. Secondary sources comprise information about production of garlic in the Czech Republic and abroad, professional literature, information from professional press, conferences papers to this topics and discussions or previous participations in professional workshops. Primary sources are based on the information gained from The Food and Agriculture Organization (FAO), the World Health Organization (WHO) and Ministry of Agriculture of the Czech Republic. Then it was necessary to select, classify and update accessible relevant information from the numerous published materials that would provide the basic knowledge of the selected topic.

The aim of the article is to analyze the production of garlic in the Czech Republic and in the world and in EU. Subsequently, the average consumer prices of garlic will be examined in the Czech Republic.

\section{Development of demand for Czech garlic in the Czech Republic}

Approximately since 1999, China's garlic has gradually become increasingly popular on our Czech market, which has become very favorite by many vendors and consumers. It had a very low selling price, which did not exceed CZK 40,- per kilogram and a really nice look (large, bright white heads of garlic). China is the largest producer of garlic in the world. Its production is estimated at 16 million to 17 million tons of garlic grown per year, with most of them being exported to countries around the world. The price of the Chinese product can be so low, especially due to cheap labor there and the use of inadmissible, but available chemicals and fertilizers. The most expensive item is the cost of exporting. The cost of shipping used by China is, however, also relatively low. For this reason, the demand for Czech garlic is declining.

In the following years, Czech farmers planted a smaller amount of garlic seedlings, which meant that the total annual of production began to drop quite a bit. Only 2239 tons of Czech garlic was harvested in 2002, even a mere 953 tons a year later. 
However, it should be noted that the season 2002/2003 was extremely unsuccessful and due to bad weather, the overall return was barely half that of the usual average. In the upcoming season, the area planted of garlic still declined, with a total of 1927 ton in 2004, a year later 1712 tons and its sales price, of course, increased. Poor, cheap garlic from China has further strengthened its newly acquired position on the Czech market. In 2006 the Spanish garlic began to import to the Czech Republic. The price was around CZK 50, - per kilogram. Its quality is higher than of Chinese, but it does not reach Czech garlic. [1-4], [7]

In 2008, the situation with garlic on the Czech market began to change slowly. From an economic point of view, between 2001 and 2008 there was a significant increase in prices for both Czech and imported garlic. This was due to different factors. The price of domestic garlic grew mainly due to a sharp drop in production and a drop in domestic demand. Chinese or Spanish garlic, after virtually destroying domestic competition and reaching its stable position on the Czech market, needed to be finally a profitable product. Logically, therefore, his price began to rise. Consumers could buy a kilogram of imported garlic from 80 to $100 \mathrm{CZK}$; the domestic garlic price was up to $300 \mathrm{CZK}$ per kilogram. However, the offer was minimal.

Although in spring 2009 demand for Czech garlic grew again and more and more consumers preferred domestic garlic before import, domestic production did not increase. Among the main reasons for the stagnation of the Czech garlic offer on the domestic market were mainly:

- the reluctance of Czech farmers to return to a very demanding and uncertain business

- lack of quality garlic seedlings

- still many consumers favoring cheaper imported garlic rather than more expensive domestic garlic

- an exclusive position of Chinese garlic on the Czech market

Due to bad weather during the whole growing season, however, there was a further decline in annual production, which reached only 1590 tons in 2009, and on the other hand, the demand for Czech garlic increased. Some growers therefore began to perceive this situation as an opportunity. On the other hand, the number of consumers who would be willing to pay for high-quality domestic garlic still did not yet reach the number that would compensate farmers to produce garlic. There is also a lack of the rate of propagation and the expression of garlic.

However, in summer 2010 Czech farmers harvested only 1457 tons of garlic, which unfortunately meant another year-on-year decline in production. The reasons were mainly low quality of garlic seedlings from abroad and significant weather fluctuations.

For the season 2010/2011, many growers retained their own controlled crop from the previous year, which they used as seedlings. This garlic, grown on the territory of the Czech Republic, was much better and more resistant to weather fluctuations. In the relatively mild winter of 2010/2011 with an average amount of snowfall, the temperature was above average. The combination of quality seedlings and ideal 
weather for garlic cultivation was the ultimate cause of better harvest. Total annual production was 1530 tons, which represented at least a slight year-on-year increase. Farmers say 2011 was the first season after a long time when they did not make a less of garlic growing. A large part of the appropriate production was again used as seed for the following season, with surplus demand for home garlic consumers rapidly and easily sold. [1-4], [7]

As a result of the successful harvest from the summer 2011, the autumn of this year is called like the "garlic mania season". The cultivation of this crop began to be published in media as a very profitable business, which naturally attracted many people.

Due of weather conditions, winter 2011/2012 was not favorable for growing garlic. Autumn and early winter was above average; so many farmers were waiting for better situation. A large amount of planted garlic has therefore faded. It is understandable, therefore, that the harvest in the summer 2012 was not successful due to the reasons described above. Annual production fell to 1272 tons of garlic grown over the previous year, although larger quantities of planting were planted in autumn. Many experienced farmers still appreciate this season, as many inexperienced growers with unscheduled planting have gone to ignorance of the problems and risks associated with growing garlic, and have left this uncertain business. The garlic was only grown for those who planted good and proven seedlings. The situation in 2013 was completely different. The total yield of garlic reached 1792 tons in the Czech Republic, thus the annual production significantly increased compared to the previous season and offered to the Czech market exceptionally high-quality goods. The reasons why there has finally been more success are several:

- farmers with experiences, who did not grow garlic for the first time, again started to grow garlic

- these farmers used in most cases high-quality Czech seed from their production, which they planted larger areas

- discovering new, much more gentle means of garlic pickling

- relatively favorable weather at the beginning of the agricultural year 2012/2013

The following season 2013/2014 was relatively favorable for domestic garlic growers. The total annual production slightly increased on the resulting 1856 tons of grown garlic, which can be considered a success due to the persistent problem with acute shortage of quality domestic seedlings. A year later, the harvest was negatively affected by lower spring temperatures and numerous rainfalls. Because of windy weather and strong storms, many plants have been damaged in some areas of the Czech Republic and a yearly decline in total garlic production to 1629 tons. The last observed season 2015/2016 is one of the above-average temperature extremes. Later varieties, due to the above-average precipitation at the beginning of summer, were better, but generally they did not grow into large dimensions. Overall, 1769 tons of domestic garlic was harvested (see Fig. 1 and Fig. 2). [1-4], [7] 


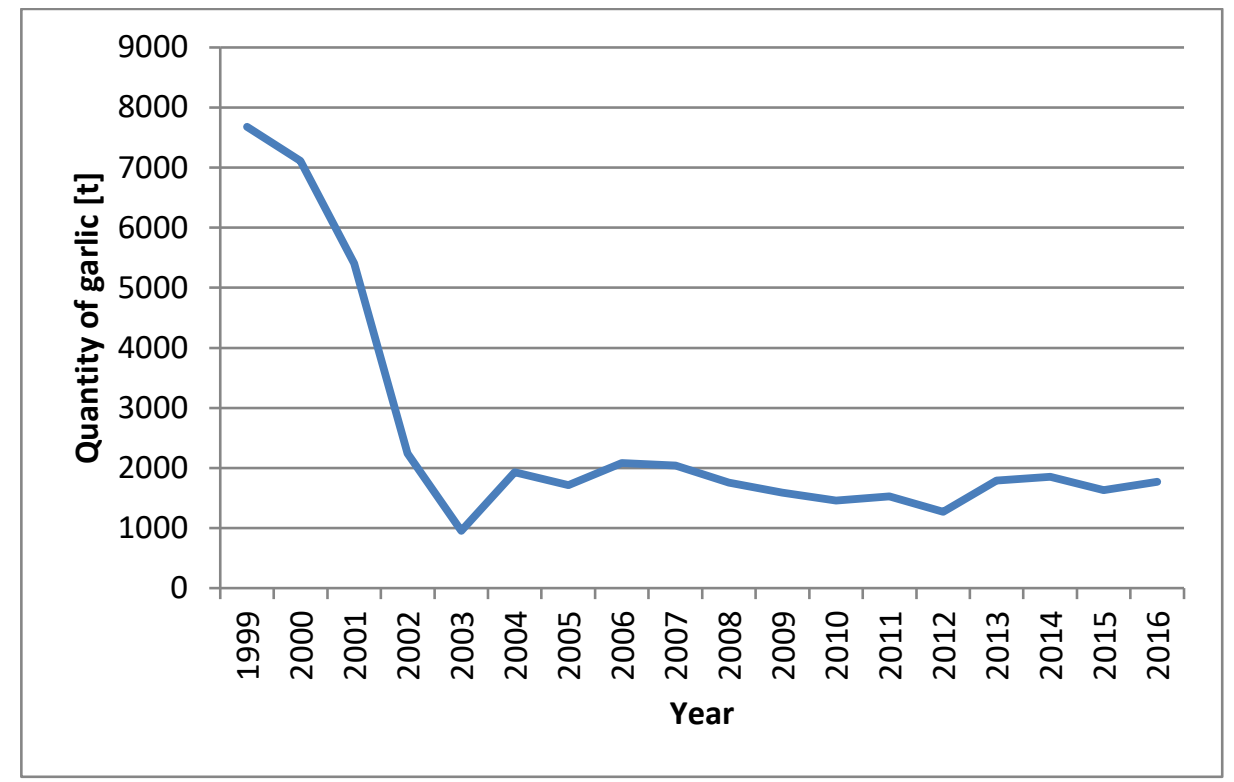

Fig. 1. Market production of garlic in the Czech Republic, [5] own processing

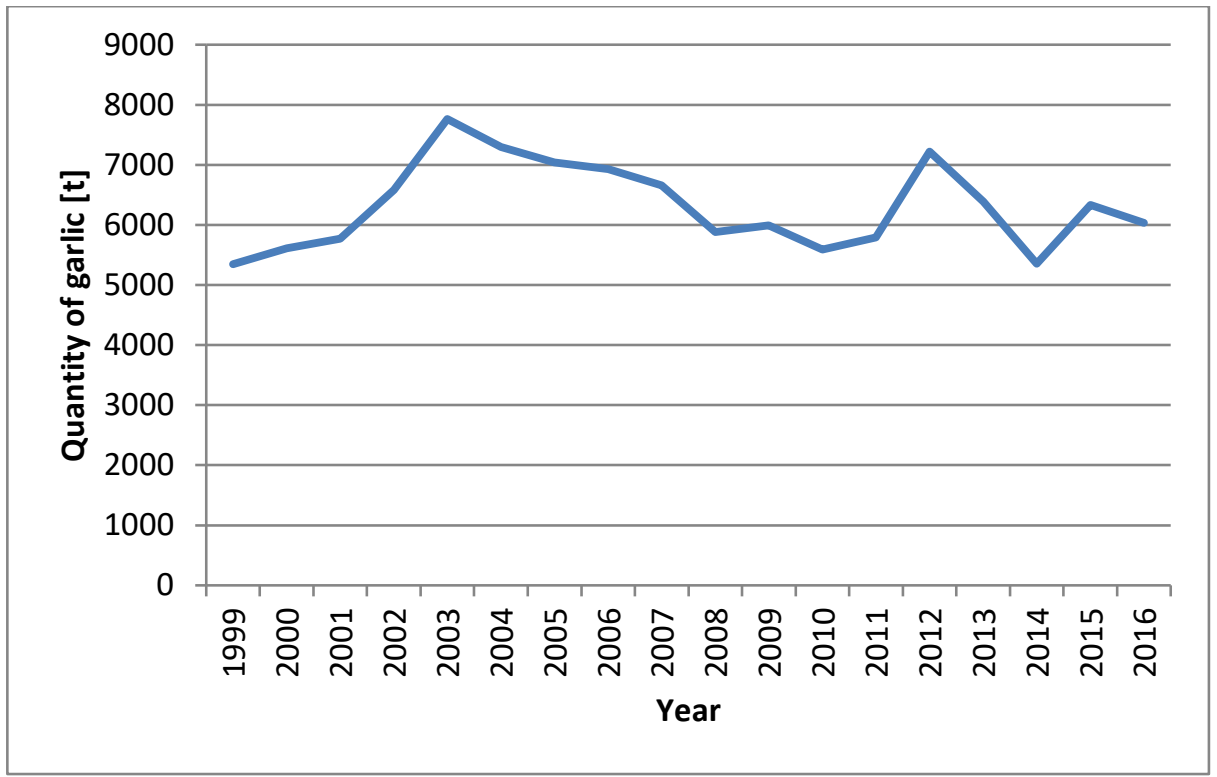

Fig. 2. Total amount of garlic imported into the Czech Republic, [5] own processing 
Domestic farmers have managed at least to stabilize the production of Czech garlic in recent years, thus preventing its complete extinction. However, efforts to increase the total amount of crops grown in this crop are still unsuccessful. The main cause is the lack of high-quality seedlings on the domestic market, which makes it impossible for most farmers to grow garlic at the required size. Since 2007, consumer interest has grown more strongly, but this does not ensure a future for the domestic product. Many people are always only orientated by price and quality while shopping, and quality is often neglected. It is therefore very important that Czech farmers continue to grow garlic, multiply the necessary seedlings, promote their promotion and thus help to gain its original dominant position on the domestic market.

\section{Comparing with world production}

Total garlic production in the European Union declined in the years 2000 and 2005, since then, it has been relatively constant and has even slightly increased in 2013. A year later, however, there was a more marked decline again. Its biggest producer is Spain, especially the Andalusian region, where garlic production increased by $15 \%$ in 2013 and the Castilla - La Mancha region, which increased the area by 6\%. However, the production of garlic from France or Poland is also significant (see Fig. 3).

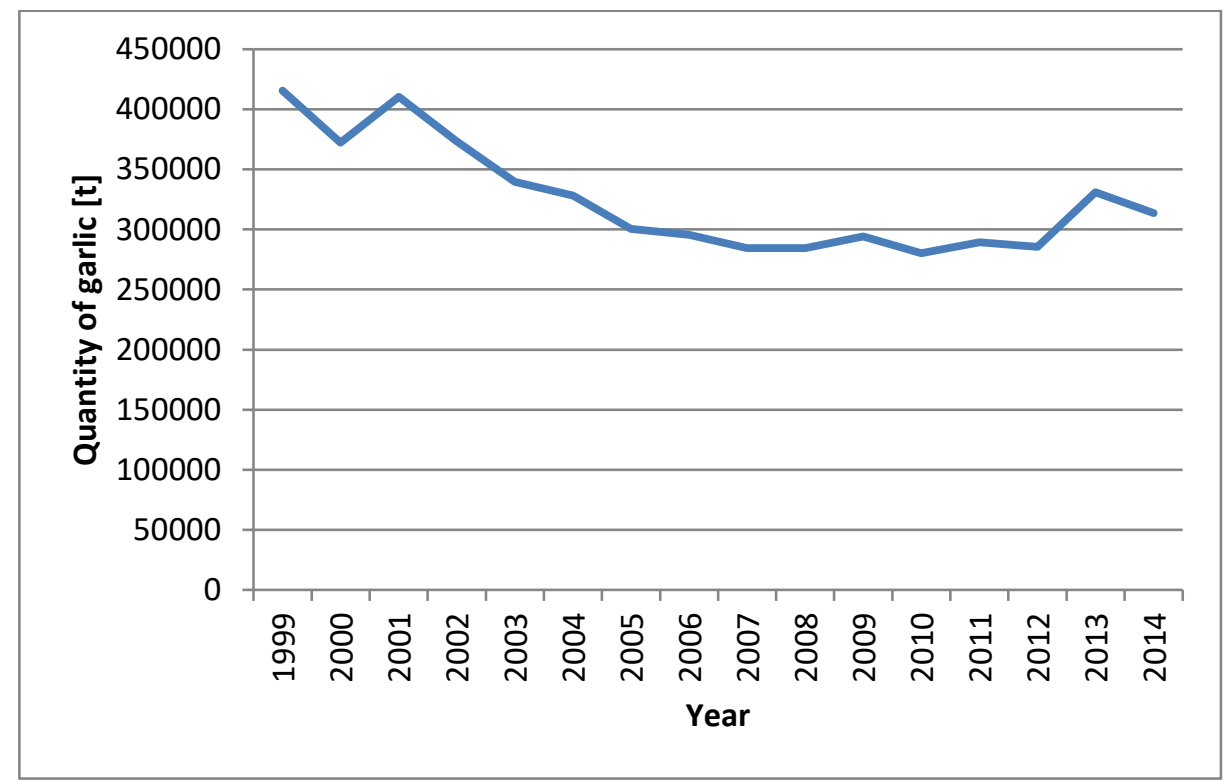

Fig. 3. Market production of garlic in the European Union, [5] own processing

China, India, South Korea, Egypt and Russia are among the world's largest garlic growers. The whole world is undoubtedly dependent on Chinese garlic production, which is enormous and is still growing. The biggest increase was recorded in 2007 
and 2008, followed by constant seasons and a further significant increase in 2013 and 2014 (see Fig. 4).

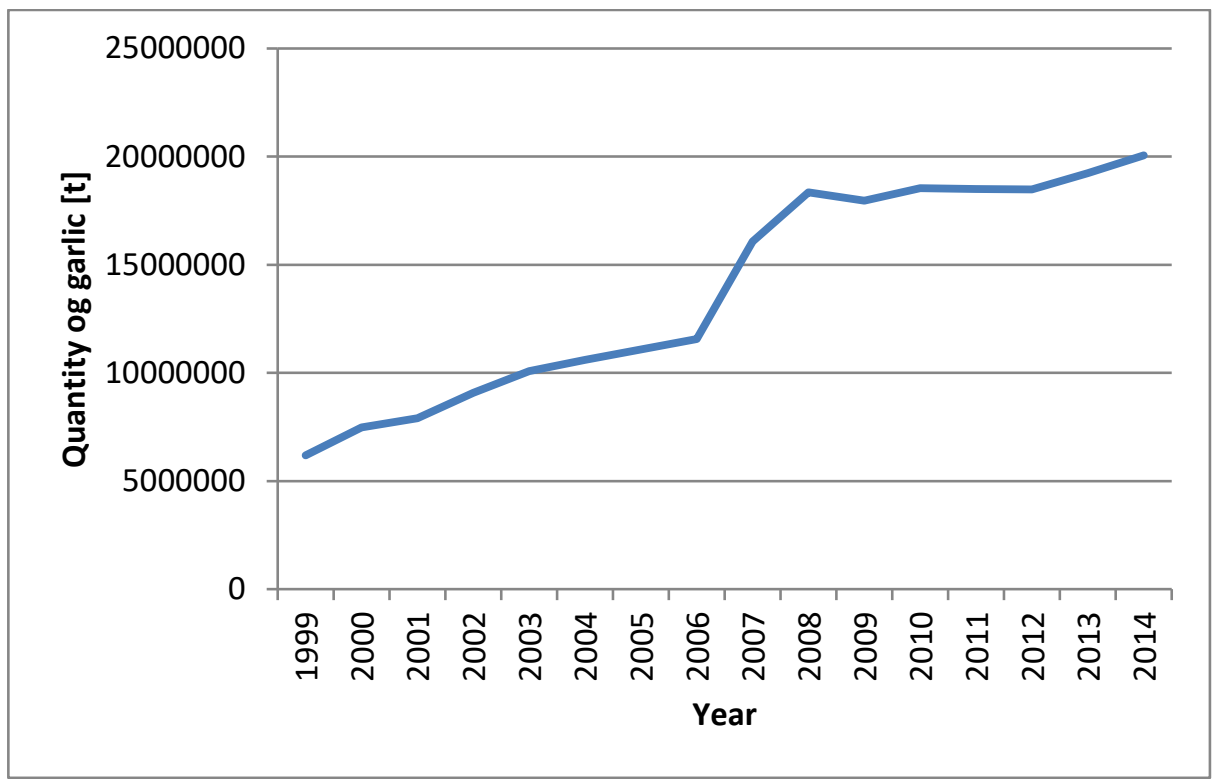

Fig. 4. Market production of garlic in China, [5] own processing

Other important world producers of garlic are the USA, whose $90 \%$ garlic is grown in California and Argentina, of which Mandoza region is surveyed with $70 \%$ garlic in Brazil and $15 \%$ in the EU and in recent years is China's major competitor. Garlic is also traditionally grown in Chile or Mexico. The total market productions of garlic in the world see in Fig. 5. 


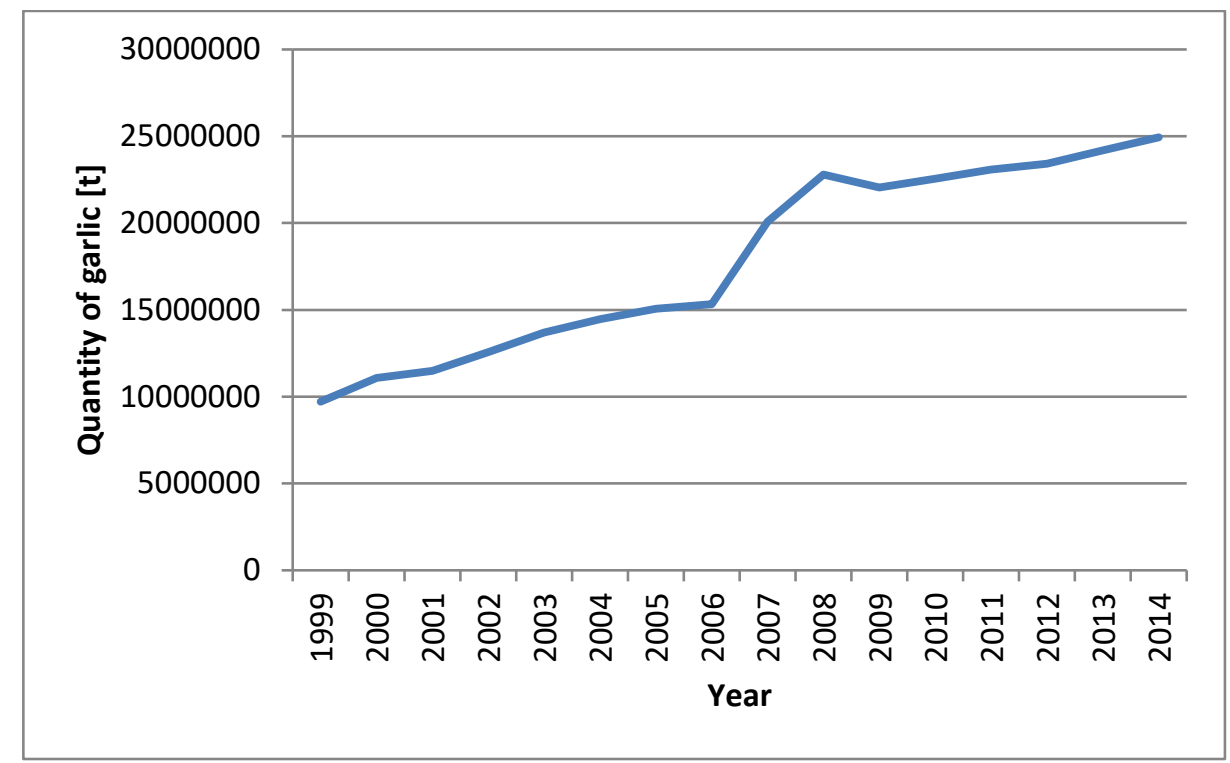

Fig. 5. Market production of garlic in the world, [5] own processing

Consumption of vegetables, expressed in the value of fresh vegetables, including vegetable products, declined again in year-on-year terms by $1.8 \%$ year-on-year, increasing consumption of salad cucumbers, peppers and lettuce. On the other hand, consumption of tomatoes, cabbage, onions, carrots, cucumber and garlic. The relatively constant consumption of garlic in the Czech Republic has been decreasing in recent years, which is probably due to the lack of a good domestic product on the market and the unwillingness of consumers to replace it with an imported substitute (see Fig. 6). 


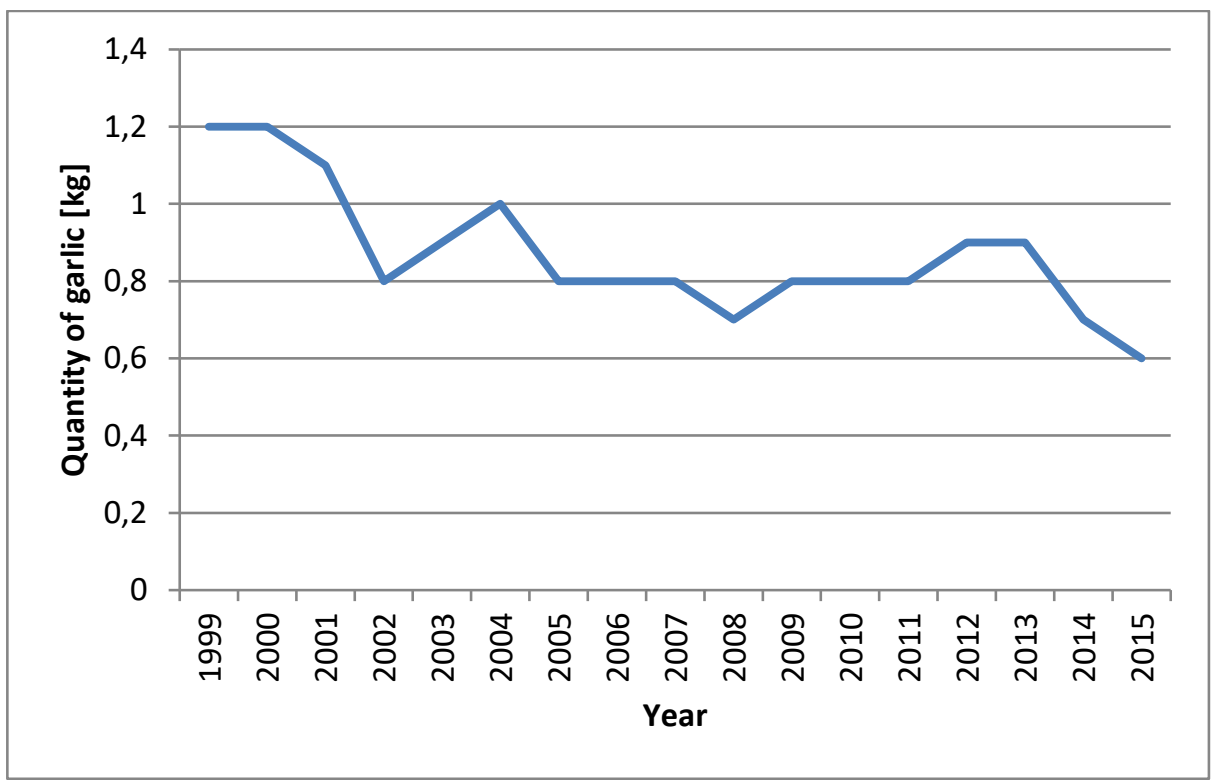

Fig. 6. Average annual consumption of garlic in the Czech Republic, [5] own processing

Currently, the United Nations Food and Agriculture Organization (FAO) and the World Health Organization (WHO) are leading a campaign to help ensure greater supply, availability and increased consumption of vegetables and fruits worldwide. Vegetables, like fruits, are an important source of a range of substances essential to healthy human nutrition. However, their consumption does not reach sufficient levels. At a global average, significantly fewer fruits and vegetables are consumed than the minimum recommended amount set by the World Health Organization; it is 400 grams per person per day. It is assumed that most people only receive about $20 \%$ to $50 \%$ of the recommended amount per day. Even if the last ones fifty years have changed the eating habits of people - at the expense of cereals and legumes, the proportion of vegetable oils, sugar and meat has grown - the proportion of fruit and vegetables has increased only slightly, and this trend continues. The World Health Organization places low consumption of fruit and vegetables on the sixth place among the twenty most risky factors causing premature deaths. Consumption of this food group ensures the supply of important substances to the body such as vitamins $\mathrm{A}, \mathrm{B}, \mathrm{C}$ and $\mathrm{E}$, fiber and other antioxidant substances.

\section{Development of average prices of Czech garlic}

The average price of garlic causes a great variety of different factors, just like with other types of vegetables. In the Czech Republic, the price of garlic of foreign competition was the most affected, which first caused a significant drop in demand for this product to almost complete cessation of its production. After a certain period 
during which consumers realized the exceptional quality of Czech garlic, there was a gradual increase in demand, but also a drop-in supply and a significant increase in the prices of this article. Czech garlic has reached the highest prices in recent years (see Fig. 7). The price of garlic is, of course, also significantly influenced by the success of the harvest in the given season and by the quality of the product (class of quality and size). It also depends very much on the demand in the given year and on the garlic variety, which are several in the Czech Republic. Some varieties are more valuable, others are less valuable.

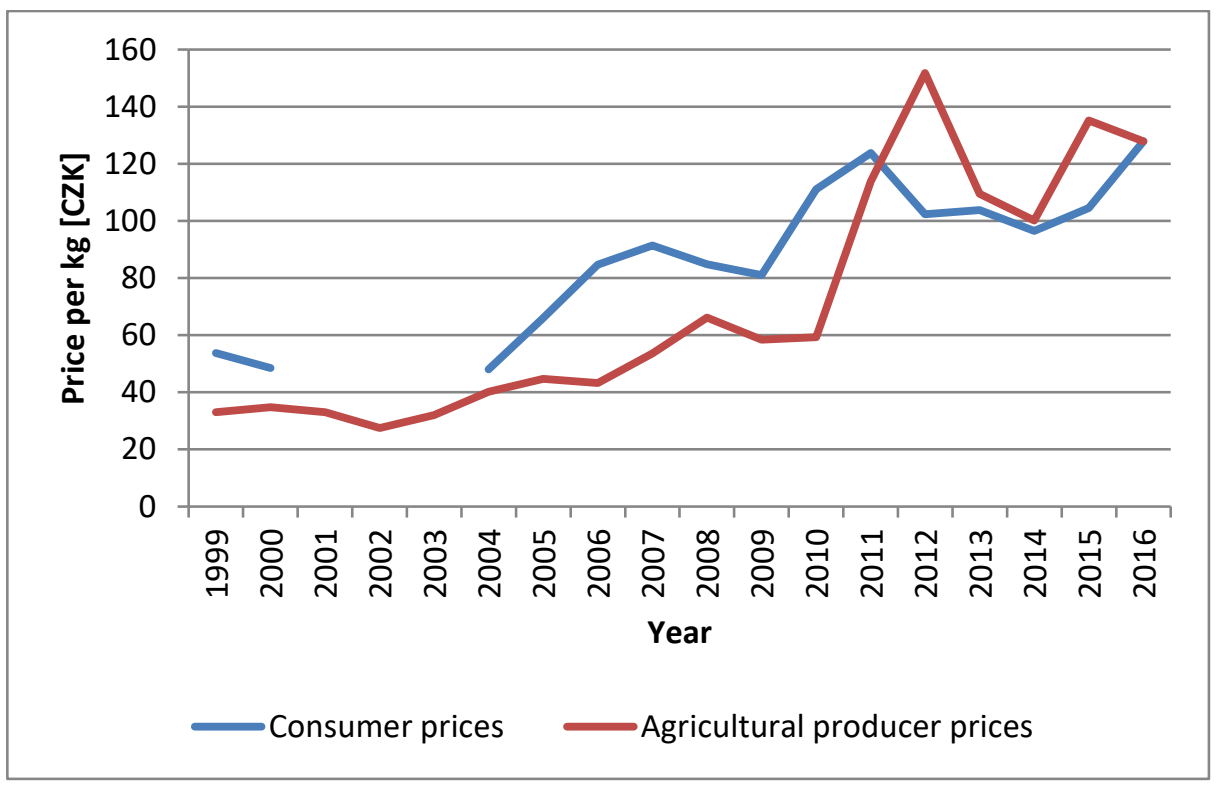

Fig. 7. Average consumer prices of garlic in the Czech Republic, [5], own processing

\section{Conclusion}

The purpose of this article was to point to a very rapid and fundamental change in the position of Czech garlic on the domestic market caused by a competitive substitute from imports, which had a negative effect on the traditional cultivation of this crop in the Czech Republic. Because of the great decline in demand for Czech garlic around 2000 , there was a significant decline in the supply of this product until the production was nearly halted. When the interest in Czech garlic started in 2009 for its high quality and perfect properties again, there was a big problem with the lack of seedlings and growers willing to return to the uncertain and very expensive business. In recent years, demand for Czech garlic has exceeded its offer several times, but production is still stagnating. The price of garlic naturally responds to the demand for the product and its limited supply and is generally growing. However, the weather in the season and the associated success of the overall production, quality, variety and 
size of the grown garlic are also influenced by its current level. Can Czech garlic regain its dominant position on the domestic market? How long can it take?

The overall development of vegetable production in the Czech Republic recorded a decrease between 1999 and 2016 in the same reporting period, but not at such a large scale as for garlic. While domestic vegetable production is mainly replaced by imports from the European Union, garlic is usually replaced by products from China, Spain or Argentina. On the contrary, Chinese garlic production has been on the rise for a long time and has a significant impact on the world's production of this crop. China is a world superpower in garlic growing and exports its product to most countries around the world. That Chinese garlic is a strong player on the market can be clearly seen on a real story of Czech production of this crop. Should we, as consumers, think more about the consequences of our not only buying behavior? Should we be the greater patriots of our country and its production?

Acknowledgements. This study is supported by internal research project No. 2103 Investment evaluation within concept Industry 4.0 at Faculty of Informatics and Management, University of Hradec Kralove, Czech Republic. We would like to thank student Martin Král for cooperation in the processing of the article.

\section{References}

1. Buchtová, I.: Situačni a výhledová zpráva ZELENINA 2013 1. ed. Prague: Ministry of Agriculture of the Czech Republic, 2013, 68 p. ISBN 978-80-7434-130-4

2. Buchtová, I.: Situačni a výhledová zpráva ZELENINA 2014 1. ed. Prague: Ministry of Agriculture of the Czech Republic, 2014, 68 p. ISBN 978-80-7434-187-8

3. Buchtová, I.: Situační a výhledová zpráva ZELENINA 2015 1. ed. Prague: Ministry of Agriculture of the Czech Republic, 2015, 66 p. ISBN 978-80-7434-260-8

4. Buchtová, I.: Situačni a výhledová zpráva ZELENINA 2016 1. ed. Prague: Ministry of Agriculture of the Czech Republic, 2016, 67 p. ISBN 978-80-7434-258-5

5. FAO, Faostat, URL: http://www.fao.org/faostat/en/\#data/QC, last accessed 2017/011/26.

6. Meena L.K., Lakra K., Bairwa Sh.L.Sen Ch.: A Study of Profile of Garlic Growers in Baran District of Rajasthan; India, Journal of Recent Advances In Agriculture, 2014, 2(6):258-262, ISSN: 2322-1534

7. Stehlík, L.: Analýza podnikatelského projektu s českým česnekem. Hradec Králové, 2017. Bakalářská práce (Bc.). Univerzita Hradec Králové, Fakulta informatiky a managementu, Katedra ekonomie, in press

8. Tindal, H.D. Vegetables in the tropics. Macmillan education limited hound mills basing toke, Hampshire, (1986). England. p. 533.

9. Zang, J., Wang, D., Zhao, G.: Mechanism of discoloration in processed garlic and onion, Trends in food science \& technology 2013 v.30 pp. 162-173, ISSN: 0924-2244, DOI: 10.1016/j.tifs.2013.01.008 